\title{
A LEGAL ANALYSIS OF SURROGATE ADVERTISING AND ITS ACCOUNTABILITY IN BRAZIL IN THE CONSUMER SOCIETY PARADIGM
}

\section{UMA ANÁLISE JURÍDICA DA SURROGATE ADVERTISING E A SUA RESPONSABILIZAÇÃO NO BRASIL NO PARADIGMA DA SOCIEDADE DE CONSUMO}

\section{MARIANA RIBEIRO SANTIAGO}

Pós-Doutorado em Direito pela Justus-Liebig-Universität Giessen (Alemanha). Doutora e Mestre em Direito pela Pontifícia Universidade Católica de São Paulo. Professora do Programa de Pós-Graduação Stricto Sensu da Universidade de Marília. Editora-Chefe da Revista Argumentum. Membro do Projeto Harmony with Nature, de iniciativa das Nações Unidas. Advogada.

\section{DANILO SCRAMIN ALVES}

Mestrando em Direito pela Universidade de Marília. Especialista em Direito e Processo do Trabalho pela Universidade Anhanguera. Analista Processual do Ministério Público do Estado do Acre. Professor do curso de Direito do Centro Universitário Uninorte. Email: dalves@mpac.mp.br.

\begin{abstract}
This paper analyses the occurrence of surrogate advertising in Brazil and the possibility to punish those involved in its broadcast. The study of the subject is justified by the observation that such advertising technique has been used to circumvent the legal limitations to certain products. The objective of the research is to verify if the Brazilian legal system has the necessary tools to deal with the surrogate advertising and what they are. To obtain the results, it was used the legal dialectic method of
\end{abstract}


approach, combined with the bibliographic method of research. It is possible to conclude that if the surrogate advertising represent misleading or abusive publicity, civil, administrative and criminal responsibility can be raised; if not, this advertisement still infringes upon the good faith, social duty and solidary duty, thus being subject to compensation.

KEYWORDS: Surrogate advertising; Publicity; Accountability; Good faith.

\section{RESUMO}

Este artigo analisa a ocorrência de surrogate advertising no Brasil e a possibilidade de punir os envolvidos em sua transmissão. O estudo do tema é justificado pela observação de que tal técnica publicitária tem sido usada para contornar as limitações legais de certos produtos. O objetivo da pesquisa é verificar se o sistema legal brasileiro possui as ferramentas necessárias para lidar com a surrogate advertising e quais são. Para obter os resultados, utilizou-se o método de abordagem dialético jurídico, combinado com o método bibliográfico de pesquisa. É possível concluir que, se a surrogate advertising representa publicidade enganosa ou abusiva, a responsabilidade civil, administrativa e criminal pode ser aplicada; caso contrário, este anúncio ainda infringe a boa-fé objetiva, a função social e solidária, estando, portanto, sujeito a indenização.

PALAVRAS-CHAVE: Surrogate advertising; Publicidade; Responsabilidade; Boa-fé.

\section{INTRODUCTION}

In today's society, consumerism has become one of the pillars of human relations, even if it is hard to identify if this process happened naturally or if it was artificially promoted by companies, as a way to raise profits.

Amongst the means used by companies to promote their products and services, advertisements are the main instrument used, and their impact on society 
has been recognized.

This fact forced many countries to stipulate legal control on advertisements, including, at times, the limitation or banning of the advertising on certain products or services, as a way to protect consumers, the environment and society as a whole from the harmful effects of the unregulated consumption of that goods may bring forward.

However, state officials must be attentive to innovative ways companies find to circumvent these rules and keep up with the law, like surrogate advertising. This justifies the need to study the occurrence of surrogate advertising and the possibilities for the accountability for its practice.

The objective of the research is to verify if the Brazilian legal system has the necessary tools to deal with the surrogate advertising and what they are, taking into account Brazilian legislation in several areas.

At first, an analysis of the treatment that Brazilian legislators have given to the control of publicity is necessary. After that, the purpose is to identify the specific kind that has been referred as surrogate advertising and the possibilities for the accountability of surrogate advertising in Brazil are debated.

To obtain the results sought by this paper, a bibliographical research covering national and international works that are specialized in the theory of publicity and the specific institute that is surrogate advertising was performed.

In the approach, the method followed was the dialectic applied to legal studies, covering, simultaneously, the phenomenon, concrete fact and theory, seeking the result with the confrontation between them.

\section{THE LEGAL TREATMENT OF ADVERTISINGS IN BRAZIL AND THE CONTEXT OF THE CONSUMER SOCIETY}

The consumer society is based on the idea of absolute satisfaction of human desires. Such a promise, however, is seductive only as long as desire remains unrealized and what becomes permanent is, in fact, dissatisfaction. (BAUMAN, 2007, p. 106)

The dissatisfaction begins when products, soon after acquired, are 
depreciated and devalued by the market or, still, awaken new desires, for new products. Thus "necessity" becomes compulsion or vice. (BAUMAN, 2007, p. 106-107)

From the moment that not the goods, but the image of these goods becomes accessible to the whole of society, the signs of consumer culture are characterized. A whole context of images and symbols are created and recreated about goods, which reflects in new forms of behavior, in the way of feeling and thinking of a large part of Western society. (TASCHNER, 2009, p. 52)

The term "consumer culture" emphasizes the importance of the commodity world and its structuring principles for the understanding of contemporary society, within a dual focus, which verifies the cultural dimension of the economy, through the use of material goods as communicating symbols, and the economy of cultural goods, according to market principles (supply, demand, capital accumulation, competition and monopolization), operating in the sphere of lifestyles. (FEATHERSTONE, 1995, p. 121)

In this context, consumer culture stimulates the play of differences, preaching that these need to be recognized and legitimized socially. As a consequence, alterity and individuality tend to be unrecognizable. (FEATHERSTONE, 1995, p. 124)

It can be said that the era of consumption, based on accelerated productivity under the sign of capital, also represents the era of radical alienation. The logic of the commodity prevails in regulating the whole culture, from the work processes to the question of sexuality. It is believed that everything can be spectacularized, orchestrated in images, consumable. (BAUDRILLARD, 2010, p. 261)

In summary, the general process of consumption, transmuted into spectacle, reaches the image and the very soul of man. The individual being and its reflections are abolished in the face of the emission and reception of signs. The man of consumption does not concern his own needs and his own image, being made in the image of the signs that he orders. Society thinks and speaks as a society of consumption, and, while consuming, consumes itself in idea. Advertising is the fundamental hymn of this new world. (BAUDRILLARD, 2010, pp. 261-262, 264)

The consumer society thus makes fundamental the deep study of the subject of advertising, in its minutiae and subtleties.

Advertising is the process through which a company or a product or service 
provider makes its product, service, brand or product message known by those who might become their clients or consumers. However, it is important to notice that this idea is generic in a way that it does not encompass all kinds of advertising, nor does it establish its elements.

Historically, Pasqualotto (1997, p. 20) already recognized that, despite the fact that there is not one universal definition for advertising even amongst those who work with it, there are some elements that are common and recurrent: sponsorship or patronage, which goes beyond the simple payment and encompasses the production and support; impersonality, considering advertisement pieces do not promote people; products or services, institutions or ideas; information, normally in regards to the characteristics of the product or service; persuasion, which refers to the wanted effect of directing consumers to purchasing the product or service; and a direction to the general mass of people, even if what is advertised has a specific market niche as destination.

On the other hand, the American Association of Advertising Agencies (AAAA), according to Benjamin, Marques and Bessa (2017, pp. 297/298), defines advertising as any kind of paid personal presentation or promotion of ideas, products or services that has been financed by an identified patron. The authors defend then that there are two essential elements to any kind of advertisement: information, a material element of publicity that represents its means of expression, and diffusion, the finalistic element, considering the main objective of advertising is to inform consumers.

Gomes (2001), however, went further when defining advertising. The author points out that advertising is constituted by three technical constraints: a product or a service in quantities that justify the use of mass means to its promotion; the planning, creation and production of an ad, or a group of ads, which will be called a campaign; and the broadcast of said ad or campaign, paid by a patron.

It is also important to point out the difference between advertising and propaganda, because despite being used distinctly in Brazilian legislations, the two concepts are normally regarded as synonyms by the Brazilian population (GRINOVER et al., 2011). In fact, most of the times when Brazilians use the terminology propaganda, they actually mean advertising or advertisement. This has caused many instances in which one word has been used in the other's stead, which has 
necessitated researchers to embark on a long mission to differentiate both (GOMES, 2001).

Most Brazilian authors differentiate propaganda and advertising by the objective of the act. While advertisings have a commercial interest, propagandas are used as a means to broadcast information with an ideological, religious, philosophical, political, economic or social intent (BENJAMIN et al., 2017).

Gomes (2001) reveals that, while both advertisings or commercials and propagandas have informative capacity and persuasive force, the main difference between both is the commercial character the first has, while the second is principally ideological. It is interesting to note that the professor calls attention to the fact that, while the idea of publicity or advertising has many different translations according to the language of the country (for instance, publicidade in Portuguese, publicitá in Italian, Werbung in German, publicité in French and publicidad in Spanish), the word propaganda keeps itself unchanged in all those languages. The difference in definition is also maintained.

Although the distinction between these two concepts may seem simple, Grinover et al. (2011) indicate that, in a deeper analysis, it is possible to identify more complex aspects to it. The authors mention that advertisements are destined to promote profit, either by making the product or service reach new consumers or by keeping previous consumers interested in them, while propagandas have as an objective to promote adherence to an ideological system.

Benjamin, Marques and Bessa (2017) also identify two separate kinds of advertising: the institutional, which is used to give publicity to a company or a brand, and the promotional, which is destined to advertise products and services.

However, as it will be mentioned next, Brazil has yet to recognize a third kind of advertisement, internationally known as Surrogate Advertising, which is the center piece of this paper.

Brazilian legislators have treated advertisements in opposite ways throughout the years. In the past, as Pasqualotto (1997) points out, Brazilian jurisprudence and doctrinators gave little to no relevance to advertisings, considering them to be mere invitations to participate in a negotiation, thus not being able to harm consumers. Brazilian tribunals interpreted the few regulatory norms that might have been used to 
control or at least limit advertisements in a very restrictive way, stating that it was the consumer's responsibility to recognize merchants' excesses and analyze products and services before effectively acquiring them.

For instance, the interpretation of article 1,512 of the previous Brazilian Civil Code was in the sense that commercial ads lack seriousness and truthfulness to bind their promoters. This was a direct consequence of Brazil's first interpretation that consumer relations were merely contractual.

This means that, unless all prerequisites for a contract were met and the consumer was able to prove a direct link between the damage suffered and the advertisement, while also repelling the caveat emptor, which established the rule that buyers had to protect themselves from merchants' astuteness, would the State intervene (BENJAMIN et al., 2017).

It is interesting to point out that, then, Brazilian jurists defended the existence of dolus bonus and dolus malus (PASQUALOTTO, 1997, p. 71). Their interpretation was that every publicity had a certain level of deceit. This deceit could be small or insignificant enough that it was part of the narrative, thus not being used to harm consumers (dolus bonus).

This had no juridical relevance. In fact, the occurrence of slight differences in publicity either caused by the changes created by telematics, for making things prettier or simpler, or for the purpose of developing the storytelling has been recently called "advertising license", and it is still not prohibited nowadays (NUNES, 2018, pp. $559 / 560)$, even though its limits are much more coherent to the need for the protection of consumers now.

Only when the advertisers effectively wanted to delude consumers enough that they would be harmed, which characterized dolus malus, that the event deserved to be brought to court and prosecuted.

This paradigm started to change the same time that civil relations became more developed and the State started to intermeddle in private negotiations as a means to protect society as a whole from damaging or fraudulent businesses.

As the third generation of rights was recognized, thus effectively identifying collectivity as a subject of rights, consumer legislations that went further than the strict contract protection started being inserted into Brazilian's legal system. 
Pasqualotto (1997, p. 75) asserts that there was a gradual shift of the legislative indifference towards advertisements. One of the first registers of a norm that controlled or limited publicity was Decree n. 4,113, from 1942, which regulated ads on health professionals such as doctors, dentists and nurses. The same kind of control was issued to lawyers through Law n. 4,215/1963.

Other interesting legislations from that period were Decree n. 7.669/1945, which stipulated that products whose publicity referenced guarana must have this plant in their composition, Law n. 5.768/1971, which disposed about the free distribution of prizes as advertisement, and Law n. $6.463 / 1977$, which made it mandatory for ads to have the full total price of products and services.

At the same time as these legislations were passed, jurisprudence also changed in order to recognize the effects publicity had on contracts and civil negotiations (PASQUALOTTO, 1997, pp. 73/74).

However, it was not until Brazil's current Constitution, from 1988, and the promulgation of the Brazilian Code of Consumer Defense, normally referred to as CDC in Portuguese, in 1990, that advertisings were generically and broadly regulated.

In 1988, the new Federal Constitution of Brazil elevated the defense of consumers as a fundamental right, including it in its fifth article, and recognized it as one of Brazil's economic principles in its article 170. The Constitution also determined that Congress had 120 days to instate a specific law to regulate the defense of consumers.

It was in 1990 that Brazilian Code of Consumer Protection (in Portuguese, Código de Defesa do Consumidor), generally called CDC, was registered as law number 8,078 and promulgated on September $11^{\text {th }}$.

This new law changed the overpast instance Brazil had on publicity, stating that all adverts had to be loyal to facts, transparent in their messages and permeated in good faith. As Braga Netto (2018) affirms, CDC is incisive in its protection of consumers against harmful effects caused by advertisements.

Brazilian CDC regulates advertising in different points. It establishes, for example, that every publicity must be advertised in such a way that consumers can easily and immediately identify it as an ad (article 36), and also that the protection against misleading and abusive publicity, which are prohibited, is a basic right of 
consumers (article $6^{\text {th }}$ ).

Articles 36, 37 and 38 specifically target publicity. At first, it is defined that the supplier of a product or service, when advertising it, must keep, for the information of the legitimate interested parties, the factual, technical and scientific data that support the message broadcast. After that, the code of consumers defines the two main illegal kinds of adverts.

According to the first paragraph of article 37, any type of information or communication whose intent is to advertise that is false or that is capable of misleading the consumer as to the nature, characteristics, quality, quantity, properties, origin, price and any other data from a product or service is considered misleading.

In every advertisement, the actual information about the service or product must be publicized adequately, including risks and other data that can potentially make consumers decide not to acquire it. If the information is false, even if partially, or if it makes, or has the potential to make, consumers believe something that is not true about said product or service, the advertisement is misleading, thus illegal.

As Braga Netto (2018) points out, the misleading aspect of an advert is determined objectively, which means that the supplier's intent to deceive consumers is irrelevant.

Ads that inflate the characteristics and qualities of a product or service are also included in this concept. This practice, commonly referred to as "puffing" by the Brazilian consumer rights doctrine, can be misleading if the exaggeration culminates in consumers believing in false information about the product or service being advertised (BENJAMIN et al., 2017).

An advertisement can also be misleading if it lacks or omits information that is necessary for the complete understanding of the usage or the utility of a product or a service.

The misleading aspect is not dispelled if it is caused not by the action of the supplier, but another person in the process. If the supplier benefits from the deceit, even if by omission, civil reparation may be yielded.

The other immediate definition of illegal publicity is abusive advertising. According to article $37,2^{\text {nd }}$ paragraph, of the CDC, it is considered abusive every advert that is discriminatory, incites violence, explores fear or superstition, exploits a 
child's deficiency in judgment and experience, disrespects environmental values or can induce consumers to behave in a way that is harmful or dangerous to their health or safety.

This means that every piece of information disclosed by suppliers, partial or not, must recognize consumers and the society as subjects of rights, respecting their aspects and singularities.

While these two kinds of illegal advertisements are recognized as such in Brazilian legislations, it is necessary to point out two things: first, those are the aspects that make an advertisement illegal because of its own characteristics, not because of the product it advertises. Advertisings that are illegal because they publicize products that should not be publicized will be explored further on.

Second, there are more instances in which an advertisement, while not illegal per se, in the sense that it is not abusive or misleading, may be irregular, because if conflicts with other norms.

Pasqualotto (1997) points out that the regulatory norms that define advertising duties and obligations are more numerous than instances of legally recognized illicit advertisements. The author identifies that while an advertisement is illegal because it contains misleading or abusive information, there are many more cases in which said advertisement is irregular, but is not illegal, because it does not fit the concepts of illegality defined in the paragraphs of article 37 of the Code of Consumer Defense, but it still goes against another principle of this code.

In this case, the author says, the advertisement should still receive control, because it is also against the law, albeit in a more indirect way. When this happens, it means that the advertisement does not respect the systematic call for good faith the CDC foresees for consumer-supplier relations in Brazil. This also brings legal consequences to advertisers, as it will also be explored further.

If there is an allegation of an advertisement that was supposedly published with any kind of irregularity or illegality, it is the one who paid for it who is responsible to prove that the publicity is not illegal or irregular. The expense of maintaining proof also is the patron's responsibility. This is established by the article 38, of the Brazilian Code of Consumer Defense.

If the patron or even the advertiser cannot prove that the advertising is not 
illegal, thus being misleading or abusive, or irregular, in the sense that it goes against the good faith principle, both may (should) be held accountable for said illegality or irregularity.

Rizzatto Nunes (2018, p. 524) points out that, when it comes to irregular or illegal advertisements, those who can be held responsible for said transgressions are the advertiser, the advertising agency that produced it or advertised it and the advertising vehicle used. The advertiser and the agency, and the people behind them, will be jointly responsible for the infractions and damages that the advertisement produced may generate, while the vehicle will only be equally and jointly liable if it does not refuse to broadcast the publicity that infringes on regulatory standards and other applicable legal norms, or if the misleading or abusive aspect is not in the publicity but in the product or service in itself.

It is important to asseverate that, in Brazil, the control on publicity and the consequent accountability of those responsible for irregular or illegal ads is not restricted to the government.

As the image of a controlling State is undesirable, Pasqualotto (1997, p. 67) defends that the economic agents involved in publicity and advertising commit themselves to instate self-regulation as a means to prevent irregular or illegal advertisements without a direct control of officials. This has had many results throughout the world, including the Code International de Pratiques Loyales en Matière de Publicité, from 1937 in France, and the Advertising Principles of American Business and the Standards of Practice of the American Associations of Advertising Agencies, from the U.S.

In Brazil, this resulted in a private organization named Conselho Nacional de Autorregulamentação Publicitária (CONAR), which means the National Council of Advertising Self-Regulation. This organization, in its turn, created the Brazilian Code of Advertising Self-Regulation, which establishes a series of ethical norms to be followed by those working with advertisings.

Nunes $(2018$, p. 509) refers to these norms as both a directive to be followed by those who participate in the creation, production and broadcast of advertisements, and as a parameter to be used by the Judiciary in the analysis of lawsuits that involve publicity, being a subsidiary source to the existing legislation. 
When an advertisement goes against this code, an administrative process is created, either ex officio or through a complaint made by a person. These suspected infringements are analyzed and judged by chambers of the Ethics Board, however the CONAR lacks coercive power to force the compliance with the obligations of its decisions (PASQUALOTTO, 1997, p. 68).

Thus, it is been said that Brazil has adopted a mixed system of control of publicity, although some authors, including Pasqualotto (1997), dispute this using the argument that the CONAR decisions are exclusively private, not being able to produce legal effects on others.

Once identified the norms that must be respected by announcers, it is important to analyze the consequence of the disregard to these stipulations. As Pasqualotto (1997) asserts, if the advertiser fails to comply with these obligations, the action may typify illicit publicity, when misleading or abusive, or characterize a less serious infringement, if the obligations arise from the principle of good faith.

In the occurrence of an illegal advertising, the advertiser may be sued on the ground of pain and suffering, having to compensate for harm or loss. As the responsibility is joint, all three participants (advertiser, agency and vehicle) may be forced to pay (NUNES, 2018).

In breach of good faith, even if there is no direct harm, there may be a reparatory obligation of negative interest, that is, the setback caused by the fact that the consumer did not want to lose resources and time (PASQUALOTTO, 1997).

This is the civil penalty imposed to the willing participants of illegal advertising. However there are also the administrative and criminal aspects of the accountability.

The CDC provides three crimes that have direct relation to publicities in articles 67, 68 and 69.

Article 67 states that the making or the promotion of an advertisement that the person knows or should know to be misleading or abusive will be punished with detention arrest of three months to one year, and a fine.

Article 68 prescribe that making or promoting advertising that is known or ought to be known to be able to induce the consumer to behave in a harmful or dangerous way to their health or safety will be punished with detention arrest of six months to two years, and a fine. 
The last publicity related crime is related to the aforementioned obligation of suppliers and advertisers to keep documentation that proves the advertisement. If the stakeholders fail to organize factual, technical and scientific data that give the advertising support, they can be arrested for one to six months, or receive a fine.

The administrative penalties are also stated in the CDC, and they include fines, apprehension and destruction of products, cancelling of permits and interdiction. However, specifically to publicity, there are the sanctions of suppression and hindrance of the advertisement, and the counterpropaganda.

As Rizzatto Nunes (2018) points out, the Judicial Branch, once called to do so, may determine the deletion of both the ad and the campaign of the advertiser in its entirety or in parts.

The imposition of counterpropaganda is, on the other hand, the main administrative consequence of illegal or irregular advertisings. The name of the sanction may be criticized, as what is effectively seen is opposition of a contrary advertisement, thus making the vocables counterpublicity or counteradvertising more accurate. This is just semantics, however.

Counterpropaganda is the obligation to remedy as much as possible the consequences of the illegal or irregular publicity by forcing the advertisers to broadcast another advertisement with information that contradicts what was noxious about the original.

To be effective, the counterpropaganda must be advertised, if possible, in the same circumstances in which the original ad was broadcast, that is, in the same vehicle, place, frequency, dimension and time, as stated by article 60 and its first paragraph of the Brazilian Code of Consumers.

The imposition of counterpropaganda, or its exercise ex officio by the advertiser, does not remove the possibility of other penalties. Nevertheless, it is also common for the judge to impose a daily fine in case of noncompliance.

The National Council of Advertising Self-Regulation can also apply punishments that include admonition, recommendation for altering or correcting the advertisement, recommendation of suspension of the broadcast and the disclosure and publicity of CONAR's decision, in case of noncompliance. However, as mentioned before, the organ cannot force its own findings on advertisers. 
After analyzing the legal system currently used in Brazil to regulate publicity, including the system of accountability of advertisers, what is left is to identify how, or rather, if it is possible to hold suppliers responsible for surrogate advertisings in Brazil.

\section{SURROGATE ADVERTISING AND ITS ACCOUNTABILITY IN BRAZIL}

The first record of the occurrence Surrogate Advertising, according to Gupta (2012), was in the United Kingdom, not long ago, when the liquor industry started advertising other beverages and utensils instead of their regular products because of a movement created by British housewives defending that alcohol advertisings were luring away their husbands, which caused a ban on liquor ads.

In Brazil, there is not a definition for surrogate advertising, mostly because this practice is virtually unknown in the country, and apparently there have been no significant studies in this specific area. In India, however, several researchers have dedicated part of their studies to define and describe the occurrence of surrogate advertising.

For instance, Munjal (2016) defines surrogate advertising as an advertisement of a product, a brand or a product message that is telecasted with the purpose of advertising another product or brand. Gangopadhyay and Dutta (2015) go further in the definition, stating that this substitution happens because the other product is forbidden.

All throughout the world there is a number of products that, because of their production methods, health or environmental impact or intrinsic characteristics, are banned from being advertised in one or another country. However, despite the ban on the advertising of those products, referred to as demerit goods, they are still allowed to be made and sold by companies, mainly because there is still societal acceptance for these items (NAYAK et al., 2018).

This creates the issue of making consumers aware of the existence of the product and the brand, which in itself is the purpose of the restrictions on publicity. If a product has so many contrary effects on the population or on the environment, it is understandable that the State will have to limit people's access to it, or rather, their 
knowledge of it. Broadcasting information about a product has always been one of the best ways to make it known and desired, even if there has been a recent change in that paradigm because of the internet. Thus, while demand makes it unwise for governments to ban them altogether, controlling the publicity on dangerous products is an effective way to reduce their sale.

Despite that, companies and manufacturers obviously still want to have their brands and products known and accessible to the public, and, even if there was a time when people could have freer access to those goods and their ads, those enterprises want to reach a younger population who did not have this opportunity and raise their sales (KARIMIKONDA; SANKALA, 2018).

Surrogate advertising should not be mistaken for brand extension, which is a normal and desired marketing practice. Brand extension happens when companies that focus on determined products decide, through market studies and analysis of viability, to create or produce a different kind of product.

Normally, these companies tend to expand their brands to products or services that somehow connect to their original products, or that at least appropriately fit them. Coca Cola, for instance, has expanded their original product, soft drinks, many times, selling nowadays several other kinds of beverages, such as energy drinks, water (both still and sparkling or carbonated), tea, coffee, alcoholic beverages, juice and yogurt. This process is often called umbrella branding or family branding.

Sometimes, however, companies may decide to expand their brands to products that are unrelated to their original products or services, while maintaining their normal operations. For example, Disney has always expanded its own brands, but normally kept itself in the entertainment industry: it sells movies, T.V. shows, books and theme parks. Yet, the company has already reached other areas unrelated to entertainment, such as clothing, including baby clothing, and education, with English as a second language schools. To which it has already been referred as brand stretching.

Brand extensions are allowed and a normal practice, which permits companies and enterprises to broaden their operations and reach more consumers than they previously could (LAMB; HAIR JR.; MCDANIEL, 2012). The criticism that is necessary to be made is when the purpose of the new product or service is to encourage the 
consumption or the active knowledge of another product whose promotion and advertising are prohibited by law. This is not brand extension, it is surrogate advertising.

One of the most common products to suffer reductions on ads is tobacco. Many countries, including Brazil, India and the U.S., heavily restrict or ban altogether advertisings of tobacco, cigars, cigarettes, or even other products that are involved in their making such as paper (WHO, 2013). Then, companies that sell these products launch new merchandising that may or may not be related, directly or not, to tobacco items. Necessarily, those new goods do not have any restriction or ban on their advertising, and then become continuously publicized.

Another branch that has had the promotion of its products banned or at least regulated is the liquor and alcoholic beverages industry. While most countries including Brazil and the U.S. regulate alcoholic beverage advertisements, some countries have decided to ban them altogether. Countries such as India, Sri Lanka and Norway passed legislations that outlaw any or most of the adverts on liquor or alcoholic beverages (KARIMIKONDA; SANKALA, 2018).

Advertisings of guns are also sometimes reduced, restricted or banned in some countries such as in Brazil (NUNES, 2018, p. 545).

Surrogate advertising happens when companies that sell the aforementioned products reside in these countries. Instead of fully complying with the directives that prohibit advertisings, some of these companies create different products or services that are not regulated, thus divulging the brand through them (MUNJAL, 2016).

In fact, these new products and services are not really important and may even be free or advertisional only. In extreme cases, Rawat et al. (2015, p. 25) point out that the product or the service may not even exist.

There have been many instances in which the occurrence of surrogate advertising has been identified, mostly in India, where the practice has been made common, and where both tobacco and alcoholic beverages advertisements are forbidden. The authors Nayak, Balasubramaniam and Kané (2018, p. 149) have provided a list of cases of surrogate advertising from India.

For example, Wills Navy Cut, a former UK cigarette company that has been moved to India, created a line of clothing named Wills Lifestyle. After the supposed 
intent to promote the tobacco products was raised, the company rebranded itself to call its cigarettes as Navy Cut only (MUNJAL, 2016).

Many liquor companies have also used surrogate advertisements to promote their products. Royal Challenge, a whisky company from India manufactured by United Spirits Ltd, has launched and heavily publicized sports drinks and mineral water. Water has also been used by Kingfisher, a beer brewery, and Black Dog, a Scotch whisky company (MUNJAL, 2016).

Soft drinks have also been produced and promoted by companies such as Bagpiper and McDowell's, both Indian whisky enterprises.

While water, sodas and sports drinks are similar to alcoholic beverages, thus being close to the original product line, some companies develop completely different goods, unrelated to the main production.

Manikchand, a brand of chewing tobacco, has made available the Oxyrich Mineral Water, while Star, another company of the same product, made a "varied product mix comprising food products, packaged drinking mineral water, refined oil, salt, steam rice, flavored soda, candy" (NAYAK et al., 2018, p. 149).

Other companies, such as Bacardi and Seagram's Imperial Blue, both of which sell alcoholic beverages, have released music CDs, most of the times using the name of the brand in the title (MUNJAL, 2016).

Another very common type of surrogate advertising is the publicity disguised as the promotion or the sponsorship of an event or a person or group of people. Most of the times, the event is posed as an award ceremony for any number of accomplishments by certain people.

The tobacco company Godfrey Phillips, for example, created the Red and White Bravery Awards event that supposedly honors courageous people from India. However, the intent to promote the company's cigarette brand Red and White was identified, which even caused some awarded people to refuse the prize. The event has been renamed to "Godfrey Phillips National Bravery Awards" (MUNJAL, 2016).

It is also common for companies, mainly tobacco or liquor, to create stands or lounges to sell their products in music events all around the world. In most cases, this is used to circumvent laws that ban or restrict publicity on those products.

Smirnoff, a very well known and recognized vodka company from Russia, has 
regularly promoted a music event named Smirnoff Experience. It has happened in many countries, including the U.S., Brazil, India and some European States. While most of these do not ban alcoholic beverages advertisements completely, in places where they are banned such as India the event may be characterized as Surrogate Advertising (KARIMIKONDA; SANKALA, 2018).

While most of these examples refer to India, it is possible to identify the occurrence of surrogate advertisings in many other countries. However, it is necessary to point out that India has been almost exclusively the biggest researcher of this kind of marketing technique, making it the country where almost all papers and recognized cases, jurisprudence and legal actions can be found (INDIA, 2016).

There have been instances of surrogate advertising in the U.S.A., for example, despite the Indian term not having been used. Brown \& Williamson, a tobacco company which holds a cigarette brand named Kool, launched a campaign called "Kool Mixx", featuring "hip-hop artists and prizes, a themed CD, limited-edition cigarette packs with hip-hop branding and additional gifts with purchase" (TRUTH INITIATIVE, 2018).

At this moment, it is important to recognize the occurrence of surrogate advertising in Brazil. It is hard to search for specific cases of surrogate advertising in Brazil's tribunals because, as it was mentioned previously, this concept is not known, much less named.

However, considering the existence of many products and services that have controlled or banned publicity, it is possible to say that the practice occurs, even if sporadically. It is necessary, thusly, to list some of these products.

The Federal Constitution stated, in its article 220, $4^{\text {th }}$ paragraph, that advertisings on tobacco, alcoholic beverages, pesticides, medicine and therapies would have been restricted by a specific law.

In Brazil, the law that the Constitution foresaw was instated in July 15, 1996, and received the number 9294. It was known as Murad Law and, at first, it only limited advertisings on tobacco, alcoholic beverages, pesticides, medicine and therapies. However, in 2000, through the modifications brought by Law n. 10167, it was changed to impose a complete ban on tobacco advertisings, except on points of sale.

There are, of course, other products and services whose advertisings were also targeted. 
Brazil, for instance, has heavily restricted advertisings on guns, establishing that any announcements on weapons for shooting must not cause fear or terror, nor have emotional appeals, dramatic situations or information that induce consumers to the conviction that guns are the only means of defense within reach. These rules, created by article 268 of Decree 3665, have also defined that gun advertisings can only be broadcast from 11 p.m. to 6 a.m., amongst other limitations.

However, none of these limitations are as severe as the almost complete ban on tobacco advertising.

It is undeniable that this aggressive restriction on tobacco ads created a series of discourses questioning the limitation of commercial freedom, including the freedom of speech of companies which work in those fields. This has not been exclusive to Brazil.

When Europe set controls on tobacco advertising, as Howells (2015) indicates, the article 10, number 1 , of the European Convention of Human Rights, which recognizes freedom of speech, was brought up. It was aroused if advertising is a form of expression.

However, the European court decided that, regardless of this protection of free speech, the limitation from the number 2 of article 10 would also apply. It states that the exercise of freedom of speech may be restricted because of the duties and responsibilities it carries.

The same questions were brought up in many European countries, but failed to result in the cancelation of laws regulating tobacco (HOWELLS, 2015).

In the United States, the process was the inverse. As Berman (2015) specifies, at first, commercial speech was not recognized as free speech, thus not being protected by the First Amendment of the American Constitution. So, then, each American state had freedom to decide whether or not to restrict advertising. This was later changed, and the Supreme Court has been analyzing, case by case, together with the states, the existence of commercial free speech.

Berman (2015) identifies that the Supreme Court has been leaning towards the maintenance of the free speech of companies, even with the risks brought by the advertisements. This was shown when the advertising on alcoholic beverages was liberated by the Supreme Court. 
When this law was made, it suffered a Direct Action of Unconstitutionality $\mathrm{n}$. 3311 against its articles restricting tobacco advertising on the basis that they illegally limit freedom of speech. It was also argued that the Federal Constitution only permitted limiting ads on tobacco, and not the complete ban the new law instated, and that this measure is not proportional (RESENDE, 2016).

Miragem and Marques (2015) dispute the argument that the ban is unconstitutional because it limits free speech by saying that this is a case of antinomy between constitutional principles, as, while speech is protected, so is life and health. Resende (2016) defends also that.

In regards to the impossibility of complete banning of tobacco advertisings, Resende (2016) argues that the Framework Convention on Tobacco Control was inserted in Brazil's Constitution through its $5^{\text {th }}$ article, and it establishes, in its article 13 , the very possibility of the ban, thus creating another antinomy between constitutional norms.

In both these cases, it is defended that the ban on tobacco advertising is necessary and more important, because it protects people from the temptation of smoking, and it is effective on ending the epidemic of tobacco usage, thus having as primary purpose the protection of life, dignity and human health. Also, it is argued that, in Brazil, advertisings are included in freedom of initiative and not freedom of speech. The first is an economic principle, the second a fundamental right (RESENDE, 2016).

Lastly, both Resende (2016) and Miragem and Marques (2015) review the principle of proportionality. The authors identified that this principle is an optimization warrant (Optimierungsgebote) and is composed by three subprinciples: adequacy, necessity and strict proportionality.

The ban on tobacco advertising, Resende (2016) defends, meets these criteria because it is adequate as it is apt and able to reduce the consumption of tobacco products and even hinder new people from starting to use said products, thus being beneficial to public health; it is necessary because it is the only policy that may effectively protect people's health from the harmful effects of smoking; and it is strictly proportional because it sacrifices commercial and speech freedom to guarantee a decent and health life to the population.

The conclusion that can be made is that, despite the fact that the action has 
not been updated for the last two years, it is probable that the constitutionality of the ban on tobacco advertisings will be recognized.

So, considering the aforementioned restriction on advertisings and the interest of tobacco companies in selling their products, the occurrence of surrogate advertising in Brazil is not only possible in this specific niche, but it is possible to recognize instances in which this practice may have happened.

In 2017, the British American Tobacco brand Kent, affiliated to the Brazilian company Souza Cruz, created a campaign named Aheadbr. This campaign involved music and young people. It is even difficult to identify exactly what the purpose of the campaign was.

However, the result was that many "digital influencers", that is, people who post pictures and videos on social media and are followed by large groups of people, posted photos smoking or holding cigarettes, many of which could be identified as Kent. There was even a photo of a package of cigarettes posted to the social media Instagram.

CONAR issued an administrative process against the campaign after a consumer represented the photos. Despite the answers of the company and the agencies involved, the illicitness was found to be true and the occurrence of surrogate advertising could be attested, even though this terminology is not yet recognized in Brazil. The company was ordered to withdraw those pictures, and an admonishing warning was issued.

Another possible case of surrogate advertising is the existence of "Revista Souza Cruz". In this case, a magazine was issued with the apparent intent to promote poetry, literature, chronicles, publicity, female-gender issues and visual arts. Without going into the merits of the dubious and uninteresting quality of the magazine's themes, it is clear, by the simple fact that the magazine is named "Souza Cruz", the same name of one of the biggest tobacco companies in Brazil, that this magazine works as an advertisement.

This magazine originally ran from 1916 to 1935 , and in 2018, a new edition was issued. According to its website, the magazine was donated to libraries and universities. Up until the production of this paper, there is not any indication that there has been any investigation or prosecution of the magazine. 
Such occurrences, if happened in India, which has consistently fought against surrogate advertising, there would be laws that could be applied, such as the Cable Television Networks Act, the Cigarettes and Other Products Act and the Advertising Standard Council of India Code, all of which regulate surrogate advertising specifically (GUPAT, 2012). Brazil does not have such regulations.

The lack of legal identification of surrogate advertising makes it difficult to link this occurrence to the types of illegal advertising, namely misleading or abusive advertising.

Considering the definition of misleading advertising, it is difficult for a surrogate advertisement to characterize it, because, although the ad-prohibited good is promoted with the main product or service, the advertising still focuses on this original item. Thus, the advertising, instead of fooling consumers, just divulges a new product or service, while the other information hitchhikes.

However, if the new product or service does not appear in the publicity, or does not even exist, the intent to mislead consumers becomes more debatable, so it is possible to use the penalties used for misleading advertising.

Also, if the forbidden product is in any way advertised, considering it is illegal, this publicity is abusive and then it will be subject to the civil, administrative and criminal penalties mentioned previously.

If the advertisement does not configure any of those two, it is not illegal. Still, the intent to indirectly advertise products that should not be advertised goes against the necessary good faith with which suppliers, advertisers, agents and vehicles must perform their activities.

Regardless of the antinomy between the fundamental constitutional rights raised by companies to question the ban on some products' advertisements, it is possible to say that the intent behind this ban is to raise the population's health and well being. So, any effort to unlawfully dodge the block on the ban means a direct attack on the policies established by the Federal Constitution itself.

It is unquestionable that publicity exercises great influence on the behavior of consumers. This is even recognized by CONAR's code of self-regulation, in its $7^{\text {th }}$ article. Thus, an advertisement that does not respect a very important public policy does not respect the whole society and their social responsibility. Perhaps it could go 
even further than the strict definitions of social function and responsibility.

Santiago and Campello (2016) have found that a company's responsibility goes beyond the regular and basic social duty in a consumer society like the one today. It is also its role to active oppose pathological consumerism, including consumer habits that are not only harmful to the person who uses the product, but to society and the environment as a whole. So, a company not only has a negative requirement, called social duty that is not to disrespect society, but also a positive one, that is to collaborate to its healthy development. The authors named it solidary function or duty.

Surrogate advertising is indisputably a disregard of good faith, social and solidary duties. Thus, it is necessary for the agencies responsible for the protection of consumers in Brazil to investigate and punish this practice.

This breech of societal responsibility may result in the need for compensation for collective damages. In Brazil's legal system, this can be achieved through an action moved in the interest of the people, as stated by law n. 7347/85.

At the same time, once identified and proved that there has been an instance of surrogate advertising, the CONAR can hold the advertiser, the agency and the vehicle responsible and apply the penalties it has at its disposal, including admonition, recommendation for altering or correcting the advertisement, recommendation of suspension of the broadcast and the disclosure and publicity of CONAR's decision, in case of noncompliance.

All these consequences are similar to the ones described by Gupta (2012) as the punitive actions stated by Indian laws, which have been used in concrete cases before.

Thus, it is possible to say that, if correctly applied, these penalties should be enough to curb the practice of surrogate advertising, thus effectively pushing society towards a better, healthier future.

\section{CONCLUSION}

The occurrence of surrogate advertising, that is the promotion of publicity on products and services created for the sole purpose of advertising another product or 
service whose publicity is banned, has been recognized, including in Brazil, where despite the lack of awareness of its existence the practice can already be visualized and identified.

In countries such as India, this proceeding has been deemed illegal or at least irregular, and its use causes consequences for the involved parties, as it is an unlawful attempt to stand up to the laws that ban the advertisement of specific products.

In Brazil, if the requirements for the configuration of misleading or abusive advertising are fulfilled, then the surrogate advertisement must be treated as such, considering both practices are perceived as illegal publicity. In these cases, the civil, administrative and criminal responsibilities must be brought.

In cases in which the ad does not represent an illegal advertising, but is still surrogate advertising, there is still a break on the necessary good faith, social duty and solidary duty of the involved companies and that must result in their accountability.

In these instances, the advertiser, the agency and the vehicle may suffer admonition, recommendation for altering or correcting the advertisement, recommendation of suspension of the broadcast and the disclosure and publicity of CONAR's decision, in case of noncompliance.

What is important is that this occurrence, both in Brazil and in other countries, must be hindered by the government, as a means to protect society and assert the public policies.

\section{REFERENCES}

BAUMAN, Zygmund. Vida Liquida. Tradução Carlos Alberto Medeiros. Rio de Janeiro: Jorge Zahar, 2007.

BENJAMIN, Antônio Herman de Vasconcellos; MARQUES, Cláudia Lima; BESSA, Leonardo Roscoe. Manual de Direito do Consumidor. $8^{\underline{a}}$ ed., São Paulo: Revista dos Tribunais, 2017.

BERMAN, Micah L. The commercial speech doctrine in the United States: false promise and promising approaches for protecting public health. In: PASQUALOTTO, Adalberto (org.). Publicidade de tabaco: frente e verso da liberdade de expressão. São Paulo: Atlas, 2015. p. 202-214.

BAUDRILLARD, Jean. A sociedade de consumo. S/L: Edições 70, 2010. 
BRAGA NETTO, Felipe Peixoto. Manual de Direito do Consumidor à Luz da Jurisprudência do STJ. 13ª ed., rev., atu. e amp., Salvador: JusPodivm, 2018.

BRASIL. Código de Defesa do Consumidor. Brasília, DF: Presidência da República, 1990. Disponível em: http://www.planalto.gov.br/ccivil_03/Leis/L807

8compilado.htm. Acesso em: 18 dez. 2018.

DEARO, Guilherme. Campanha de cigarro usa publicidade ilegal e disfarçada. Exame. São Paulo, 07 nov. 2017, 17:20. Disponível em: https://exame.abril.com.br/marketing/disfarcada-campanha-cigarro-kent-instagr am-influencers/. Acesso em: 01 fev. 2019, 10:05.

FEATHERSTONE, Mike. Cultura de consumo e pós-modernismo. Tradução Julio Assis Simões. São Paulo: Studio Nobel, 1995.

GANGOPADHYAY, Saswati; DUTTA, Soumya. Surrogate Advertising on Satellite Television: Indian Experience. Journal of Business Management, Commerce \& Research, Bhubaneswar, v. IV, n. XII, jun. 2015.

GOMES, Neusa Demartini. Publicidade ou propaganda? É isso aí! Revista FAMECOS, Porto Alegre, n. 16, p. 111-121, dez. 2001.

GRINOVER, Ada Pellegrini; BENJAMIN, Antônio Herman de Vasconcellos; FINK, Daniel Roberto; FILOMENO, José Geraldo Brito, NERY JÚNIOR, Nelson; DENARI, Zelmo. Código Brasileiro de Defesa do Consumidor: Comentado pelos Autores do Anteprojeto. 10를 ed., Rio de Janeiro: Forense, 2011.

GUPTA, Ruchi. Advertising Principles and Practice. New Delhi: S. Chand Publishing, 2012.

HOW Tobacco Companies Use Experiential Marketing. Truth Initiative, Washington D.C., 26 jun. 2018. Available at https://truthinitiative.org/news/how-tobaccocompanies-use-experiential-marketing. Accessed on $12 \mathrm{dec} .2018$.

HOWELLS, Gerraint. European and UK controls on regulation of tobacco advertising. In: PASQUALOTTO, Adalberto (org.). Publicidade de tabaco: frente e verso da liberdade de expressão. São Paulo: Atlas, 2015. p. 153-159.

INDIA. The Surrogate Advertisements (Prohibition) Bill. New Delhi, 2016. Available at: http://164.100.47.4/billstexts/rsbilltexts/AsIntroduced/surogat\%201

0317-E.pdf. Accessed on 18 jan. 2019.

KARIMIKONDA, Harinadh; SANKALA, Suneel. Generation-Y Perception towards Scaled Down and Surrogate Advertising: Alcoholic Beverages. International Research Journal of Management Science \& Technology, New Delhi, v. 9, i. 2, p. 152-162, feb. 2018. Available at http://www.irjmst.com/Artical_request?id=6551. Accessed on 12 dec. 2018. 
LAMB, Charles W.; HAIR JR., Joseph F.; MCDANIEL, Carl. Essentials of marketing. $7^{\text {th }}$ ed., Mason: South-Western Cengage Learning, 2012.

MIRAGEM, Bruna; MARQUES, Cláudia Lima. A constitucionalidade das restrições à publicidade do tabaco por lei federal: diálogo e adequação do princípio da livre iniciativa econômica à defesa do consumidor e da saúde pública. In: PASQUALOTTO, Adalberto (org.). Publicidade de tabaco: frente e verso da liberdade de expressão. São Paulo: Atlas, 2015. p. 03-37.

MUNJAL, Neha. A study on ethical issues in advertising and analyzing different unethical advertisements with results of asci decisions: an Indian perspective. Ecoforum Journal, v. 5, i. 2. Suceava, 2016. Available at http://www.ecoforumjournal.ro/index.php/eco/article/view/245. Accessed on $12 \mathrm{dec}$. 2018.

NAYAK, Sushma; BALASUBRAMANIAM, Vani; KANÉ, Amiya Prakash. Surrogate Advertising: A Clandestine Attempt ar Influencing People's Choices - The Indian Perspective. In: EPURE, Manuela; MIHĂEŞ, Lorena Clara (ed.). The Role of Language and Symbols in Promotional Strategies and Marketing Schemes. Hershey: Business Science Reference, 2018. p. 144-160.

NUNES, Rizzatto. Curso de Direito do Consumidor. São Paulo: Saraiva, 2018.

PANDA, Barcelona. Surrogate Advertisements: India's Response Towards International Regulations. New Delhi: Manupatra, 2011.

PASQUALOTTO, Adalberto. Os Efeitos Obrigacionais da Publicidade no Código de Defesa do Consumidor. São Paulo: Revista dos Tribunais, 1997.

RAWAT, Surya Rashmi; BHATIA, Kunal; HEDGE, Mihika; BHAT, Neeraj; TEWARI, Shubhangi. The Importance of Ethical Marketing Practices. Journal of Business Management And Economics, Bhopal, v. 3, n. 2, feb. 2015. p. 23-30.

RESENDE, Augusto César Leite de. A proibição da publicidade de tabaco na constituição material brasileira: reflexões a partir da convenção quadro de controle do tabaco. In: Revista Jurídica Cesumar, Maringá, v. 16, n. 3, p. 729-752, set./dez. 2016. DOI: http://dx.doi.org/10.17765/2176-9184.2016v16n3p729-752. Disponível em: https://www.researchgate.net/publication/312430874_A_Proibicao_da_Publicida de_de_Tabaco_na_Constituicao_Material_Brasileira_Reflexoes_a_partir_da_Conve ncao_Quadro_de_Controle_do_Tabaco. Acesso em: 02 jan. 2019.

SANTIAGO, Mariana Ribeiro; CAMPELLO, Livia Gaigher Bósio. Função Social e Solidária da Empresa na Dinâmica da Sociedade de Consumo. Scientia luris, Londrina, v. 20, n. 1, p. 119-143, abr. 2016. DOI: 10.5433/2178-8189.2016v20n1p119. ISSN: 2178-8189. 
SANTOS, Tarcyanie Cajueiro. Publicidade e consumo responsável. Galáxia (São Paulo), São Paulo, v. 13, n. 26, p. 201-213, dez. 2013. Disponível em http://www.scielo.br/scielo.php?script=sci_arttext\&pid=S1982-25532013000300016\&l $\mathrm{ng}=\mathrm{pt \& nrm=iso}$. Acesso em $12 \mathrm{dez} .2018$.

TASCHNER, Gisela. Cultura, consumo e cidadania. Bauru, SP: EDUSC, 2009.

WHO. Framework Convention on Tobacco Control. Geneva: WHO Document Production Services, 2013. 